\title{
The Cuban Iguana and American Jurisprudence
}

In fall 2003, attorney Tom Wilner needed to persuade the justices of the Supreme Court that it was in their interest to take the case of a dozen Kuwaiti detainees being held in isolation in Guantanamo Bay, Cuba, without charges, without a hearing, and without access

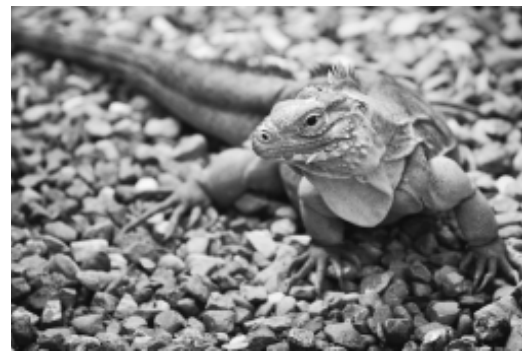
to a lawyer.

Wilner used three arguments in his elegant petition to the Court. He argued that, under the Constitution, the courts have a critical role in striking a balance between the president's need to protect our nation's security and the people's need to protect the fundamental right to a fair hearing, with a lawyer present, before a neutral decision maker.

Wilner further argued that the administration's mistreatment of the detainees and the denial of their rights under law had become an international embarrassment. Here was an opportunity for the Supreme Court to make it right.

In his third argument, Wilner referred to the example of the Cuban iguana. When the Cuban iguana crosses the Cuban border into Guantanamo, it is protected by American law, under the Endangered Species Act. However, the human beings held prisoner at Guantanamo were not protected under American law. Wilner concluded that if the Supreme Court did not review his clients' cases, the Cuban iguana would have greater safeguards than human beings at Guantanamo.

The Supreme Court agreed to hear the case. 
This page intentionally left blank 